\title{
Effects of IBA Concentrations and Different Cultural Media on the Growth of Two Type Grape Cuttings of Salt Creek 'Ramsey' Rootstock.
}

\author{
Abo- Ogiala, A. M., Neveen H. Fleafl and Elaidy, A. A. \\ Horticulture Department, Faculty of Agriculture, Seberbay Campus, Tanta University, 31527 Tanta, \\ Egypt.
}

Received on: 24-10-2021

Accepted on: 23-11-2021

\begin{abstract}
Previous studies reported that Salt Creek grape rootstock 'Ramsey' promising in grape industry that can face climatic changes which resulting soil problems that limit grape cultivation. Ramsey can tolerate salt and drought conditions without decreasing yield production. It has also high resistance to phylloxera and nematodes. From the other side cuttings of Ramsey face rooting difficulties. The aim of this study was to improve cuttings (intermediate and basal) traits of Ramsey via different cultural media (sand; sand: Peat moss, 3:1 v/v; sand: biochar, 3:0.5 v/v (Char1); sand: biochar, 3:1 v/v (Char2) and IBA concentration (0, 1000 and $2000 \mathrm{ppm})$. Cuttings growth were followed by measuring shoot length and thickness, leaves number per shoot, leaf area, root length, number of root per cutting and root thickness. In addition, cuttings nutritional status of different elements such $\mathrm{N}, \mathrm{P}, \mathrm{K}, \mathrm{Ca}$ and $\mathrm{Mg}$ were determined. Results showed that two type cuttings treated with 2000 ppm IBA were better than 1000 IBA treatment. Moreover, two type cuttings grown in Char2 media were superior on that grown in Char1 and both were superior on that grown in sand. Hence it could be concluded that using the intermediate cutting with 2000 ppm IBA in biochar media for Salt Creek grape rootstock 'Ramsey' propagation.
\end{abstract}

KEYWORDS: Salt Creek, Grape, Rootstock, Propagation, Cuttings, IBA, Cultural Media, Performance, Nutrient

\section{INTRODUCTION}

Grapevines (Vitis vinifera $\mathrm{L}$ ) production are one of the most valuable and economical crops worldwide. Increasing the demand of grapevines cultivation required developing new strategies to cope with climatic changes that limit soil cultivation. Climatic changes led to soil salinity and drought lands subsequently restricted grape cultivation. For such reasons many grape rootstocks grafted to different grape variety scion to overcome the previous mention conditions (Rieger, 2006). Salt Creek grape rootstock 'Ramsey' was found to be the highest salt and drought tolerance without affecting yield production among several tested grape rootstocks (Southey et al., 1991; Zhang et al., 2002). Migicovsky et al. (2021) examined Ramsey with 14 other grape rootstock for two scion varieties ('Chardonnay' and 'Cabernet Sauvignon') and cultivated in salt affected soil near Lodi in San Joaquin County, California in 1992 and evaluated from 1995 to 1999 . 'Ramsey' showed the highest yields with highest berry weights and the lowest Ravaz indexes which refers to the mass weight of residual pruning.

This was the reason for chosen that grape rootstock in this study but in the other hand, cuttings of Ramsey were found to be difficult in rooting as stated by many previous studies (Howell, 1987;
Hartmann et al., 2002 and Ahmed and Mokhtar, 2011). To overcome the problem of rooting difficulties of Ramsey grape rootstock many applications were recommended such dipping in synthetic auxin (IBA or IAA) as reported by Epstein and Müller (1993) and De Klerk et al., (1999).

Other studies proved that rooting media play a crucial role in increasing and improving sprouting roots on cuttings used for propagation in different fruit types (İsfendiyaroğlu et al., 2009; Sengel et al., 2012). Management media cultivation include the mixing with biochar, peat moss and compost improve and maintain soil fertility subsequently grapevine nutrient uptake (Salomé, et al. 2016; Bozzolo, et al. 2017).

Furthermore, the stem part was found to be significantly correlated with the cutting ability for rooting and success (Muhammad 2005; Waite et al., 2015).

The present study aims to:

1-Rooting evaluation of intermediate and basal stem cuttings of Salt Creek grape rootstock 'Ramsey' in different rooting media including sand soil alone or mixed with wood biochar or peat moss after dipping in indole-3-bytric acid (IBA).

2-Recommend the best suitable application for propagating Salt Creek grape rootstock 'Ramsey' 
Abo- Ogiala A.M. et al., 2021

to share the grape industry with the challenges of climatic changes that restrict grape cultivation.

\section{MATERIALS AND METHODS}

This work carried out in the experimental farm of Agricultural Faculty, Tanta University, Egypt in 2019 and 2020 seasons.

\subsection{Cuttings preparation and cultivation:-}

Residual pruning of salt creek (Ramsey) grape that grown in the Horticulture Research Institute orchard, certified source, were brought in January and used for cuttings preparation. Middle branches used to prepare intermediate cuttings and the bottom of branches used for basal cuttings. Both types of cuttings cared to have four eyes for each with almost $50-60 \mathrm{~cm}$ long. Cuttings were prepared with straight cut directly under the eye for the lower cutting part while tilted cut with enough distance over the eye was done for the upper cutting part.

The lower cuttings part were longitudinally wounded (2-3 wounds at the basal $5 \mathrm{~cm})$, Then bases of the cutting were dipped for 15 second in the different concentration of IBA as follow:-

1- Ethyl alcohol $50 \%$ without IBA (control) $50 \%)$

2- 1000 ppm IBA (soluble in ethyl alcohol $50 \%)$

3- 2000 ppm IBA (soluble in ethyl alcohol

Afterwards cuttings were left 15 minutes for air drying and stored for one month in vertical position with opposite direction, i.e, lower cuttings part were in tops and the upper cutting part were in bottom in plastic boxes filled with wet peat moss media under and over cuttings. After stored period cuttings were cultivated at the beginning of February in each season in the black plastic bags $(20 \mathrm{~cm}$ width X $30 \mathrm{~cm}$ high) filled with the described experimental media below:-

1- Sand media (control) (S)

2- Sand: peat moss, 3: $1 \mathrm{v} / \mathrm{v}(\mathrm{S}+\mathrm{P})$

3- Sand: wood biochar, 3: $0.5 \mathrm{v} / \mathrm{v}$ (Char1)

4- Sand: wood biochar, 3: $1 \mathrm{v} / \mathrm{v}$ (Char2)

Where $S$ refers to sand, $P$ to peat moss, Char1 to third treatment and Char2 to the forth treatment.

Accordingly, the experiment included 24 treatments ( 2 types of cutting $x 3$ IBA treatments $x 4$ different rooting media) and were arranged in a randomized completely design (RCD) with 3 replicates for each treatment and each replicate included ten cuttings.

\subsection{Preparation of biochar:}

Sawdust of wood as organic waste was exposed to oxygen-limited conditions as described by Lehmann and Joseph (2009) to produce biochar used in this study. Biochar was prepared by slow pyrolysis in a kiln with a retention time of $2 \mathrm{~h}$. Afterwards biochar left overnight to cool down, then crushed gently and grinded to small size particles to pass through a $0.5 \mathrm{~mm}$ sieve before use. Table (1) shows the chemical analysis of biochar prepared for that study.

Table 1. Analysis of biochar mixed with sand in this study

\begin{tabular}{cccccccccc}
\hline Prosperities & $\mathbf{p H}(\mathbf{1 : 1 0})$ & $\begin{array}{c}\mathbf{E C} \\
(\mathbf{1 : 1 0})\end{array}$ & $\begin{array}{c}\mathbf{C E C}(\mathbf{c} \mathbf{~ m o l} \\
\left.\mathbf{k g}^{-1}\right)\end{array}$ & $\begin{array}{c}\mathbf{B D}(\mathbf{g ~ c m} \\
\mathbf{3})\end{array}$ & $\begin{array}{c}\mathbf{N} \\
\mathbf{\%}\end{array}$ & $\mathbf{P} \%$ & $\begin{array}{c}\mathbf{K} \\
\mathbf{\%}\end{array}$ & $\mathbf{C} \%$ & $\begin{array}{c}\mathbf{C : N} \\
\text { ratio }\end{array}$ \\
\hline $\begin{array}{c}\text { After } \\
\text { pyrolysis }\end{array}$ & 8.70 & 2.18 & 31.5 & 0.32 & 1.91 & 0.13 & 0.92 & 65.5 & 34.3 \\
\hline
\end{tabular}

CEC (Cation Exchange Capacity), BD (Bulk Density)

2.3. Physiochemical properties of peat moss media used in this study

Washed sand was used as basic media for this experiment. Peat moss are famous as traditional mixture media with sand for soilless culture in general. Some physical and chemical characteristics of peat moss were estimated in peat moss raw material before mixing with washed sand in this study and shown in table (2).

Table 2. Analysis of peat moss mixed with sand in this study

\begin{tabular}{cccccccccc}
\hline Prosperities & $\begin{array}{c}\mathbf{p H} \\
(\mathbf{1 : 1 0})\end{array}$ & $\begin{array}{c}\mathbf{E C} \\
(\mathbf{1 : 1 0})\end{array}$ & $\mathbf{O . M} \%$ & $\mathbf{B D}\left(\mathbf{g ~ c m}^{-\mathbf{3}}\right)$ & $\begin{array}{c}\mathbf{N} \\
\mathbf{\%}\end{array}$ & $\mathbf{P} \%$ & $\mathbf{K} \%$ & $\mathbf{C} \%$ & $\begin{array}{c}\mathbf{C}: \mathbf{N} \\
\text { ratio }\end{array}$ \\
\hline Results & 6.70 & 1.18 & 95 & 0.32 & 0.91 & 0.03 & 0.02 & 55.5 & 60.99 \\
\hline
\end{tabular}

O.M (organic matter), BD (Bulk Density).

Prepared media was kept at field capacity of $60 \%$ by adding suitable amount of water with every two days as described by Weggler et al., (2008). Foliar application of NPK 20/20/20 nutrients was applied once a week early in the morning.

\subsection{Vegetative growth measurements}

Percentage of successful cuttings were estimated according to the following formula.

Success cuttings $\%$

$$
=\frac{\text { numbers of genminated cuttings }}{\text { number of planting cuttings }} \times 100
$$




\section{Scientific Journal of Agricultural Sciences 3 (2): 58-67, 2021}

shoot length (cm) parameter expressed the maximum long growth of chosen shoot that left on cutting after 90 days of cultivation, first of May each year.

Number of shoot per cutting that sprouted from cutting after 90 days of cultivation as well were also counted.

Shoot thickness (mm) referred to the shoot diameter left on cutting at the middle part of it after 90 days of cultivation.

Number of leaves per shoot meant the average leaves number of shoot on cutting after 90 days of cultivation.

Leaf area $\left(\mathbf{c m}^{2}\right)$ estimated by chosen the sixth leaf from the top of the shoot using digital planimeter according to Bremner and Keeney (1965) during June and was expressed in $\mathrm{cm}^{2}$.

\subsection{Root characteristics:}

Root length (cm) after 90 days of planting 3 successful cuttings were harvested to measure the main length for each.

Number of root per plant were counted at the time of measuring root length as well.

Root thickness (mm) measured at the middle part of the root.

\subsection{Nutritional content}

Number of leaves with petioles from the middle part of shoots of harvested cuttings after 6 months of cultivation were used for analysis, almost end of July. Harvested leaves were milled to fine powder using grinder after drying. Then $0.2 \mathrm{gm}$. powder was digested using a sulphuric acid and hydrogen peroxide till obtained clear solution. The liquid transferred to $100 \mathrm{ml}$ volumetric flask and filled with distilled water to standard labeled volume (Shawky et al., 1996). Same procedures was done with mass of roots then samples were ready for elements determination as follow:

- Nitrogen content (N) was determined using Micro-kjeldehl method as described by Page (1982).

- Phosphorus content (P) measured as described by Cotteine et al., (1982).

- Potassium content (K) followed by Flame photometer method according to Jackson (1967).

- Calcium content (Ca) followed by Perkin Elmer3300 method according to Pratt and Chapman (1961).

- Magnesium content (Mg) determined using the method of Wilde et al., (1985).

\subsection{Statistical analysis:}

Data were analyzed by Statistical Graphics Corporation, STATGRAPHICS Plus (St. Louis, MO, USA) for one way analysis of variance and expressed as mean \pm standard error (SE). The treatments means were compared using least significant difference (LSD) tested at probability 5\% as described by Gomez and Gomez (1984).

\section{Results and Discussion}

3.1. Effect of IBA and cultural media on cutting vegetative growth traits of Salt Creek grape rootstock 'Ramsey'

In general, results in Table $(3,4)$ indicated that both IBA treatments significantly improved cutting vegetative growth traits, i.e., successful cuttings rate, shoot length, number of shoot per cutting, shoot thickness, leaves number per cuttings and leaf area, which grown in all different cultural media compared to that grown in sand media as control in 2019 and 2020 seasons. The intermediate cuttings treated with 2000 ppm IBA in Char2 gave the highest value for the previous mention traits in the two seasons. The intermediate cuttings treated with 1000 ppm IBA in Char2 showed the second superior results in that concerns in the two seasons. Afterwards came the basal cuttings treated with 2000 ppm IBA grown in Char2 then followed by intermediate cuttings treated with 2000 ppm IBA grown in Char1 in both studied seasons.

The intermediate cuttings treated with 1000 ppm IBA and grown in Char1 were came afterwards, then came the basal cuttings treated with $2000 \mathrm{ppm}$ IBA and grown in Char2 followed by intermediate cuttings treated with 2000 ppm IBA grown in the mixture media of sand: peat moss followed by the intermediate cuttings treated with $1000 \mathrm{ppm}$ IBA in the same media. The intermediate cuttings free of IBA treatments and grown in Char2 were the next followed by the intermediate cuttings free of IBA treatments and grown in Char1. Afterwards, basal cuttings free of IBA treatments and grown in Char2 followed by basal cuttings free of IBA treatments and grown Char1 followed by intermediate cuttings treated with $2000 \mathrm{ppm}$ IBA and grown in sand and finally intermediate cuttings treated with $1000 \mathrm{ppm}$ IBA and grown in sand. In general, using middle cuttings were better than the basal ones. Also, cuttings cultivated in Char 2 media were better than in Char1. Similarly, treated cuttings with 2000 ppm IBA were better than those treated with $1000 \mathrm{ppm}$ IBA. These results in agreements with Satisha and Adsule (2008); Galavi et al. (2013) and FlorezSarasa et al. (2020) who reported that IBA treatments improved cutting vegetative growth traits of different grape rootstocks as well.

From the other hand, the results of Song et al. (2001) were in the same line concerning cultural media substrates where they found that mixing different cultural media with sand such vermiculite or peat moss as basic substrates induced the cuttings growth in four grape rootstocks. Other study came in 
Abo- Ogiala A.M. et al., 2021

Table 3. Effect of cultural media and IBA on percentage of successful cutting, shoot length (cm) and shoot number per cutting for intermediate and basal stem cuttings of Ramsey grape rootstock during 2019 and 2020 growing seasons.

\begin{tabular}{|c|c|c|c|c|c|c|c|}
\hline \multirow{2}{*}{\multicolumn{2}{|c|}{ Treatments }} & \multicolumn{2}{|c|}{$\begin{array}{l}\text { Successful rate } \\
\text { of cutting \% }\end{array}$} & \multicolumn{2}{|c|}{$\begin{array}{l}\text { Shoot length } \\
(\mathrm{cm})\end{array}$} & \multicolumn{2}{|c|}{$\begin{array}{c}\text { Number of shoot } \\
\text { /cutting }\end{array}$} \\
\hline & & Intermediate & basal & Intermediate & basal & Intermediate & basal \\
\hline \multirow[t]{2}{*}{ Media } & IBA (ppm) & \multicolumn{6}{|c|}{2019} \\
\hline & $\mathbf{0}$ & $39.64 \mathrm{k}$ & $33.33 \mathrm{j}$ & $31.98 \mathrm{j}$ & $29.65 \mathrm{i}$ & $1.13 \mathrm{i}$ & $1.10 \mathrm{j}$ \\
\hline \multirow[t]{3}{*}{$\mathbf{S}$} & 1000 & $43.87 \mathrm{j}$ & $40.81 \mathrm{i}$ & $36.87 \mathrm{i}$ & $34.76 \mathrm{~h}$ & $2.01 \mathrm{~h}$ & $1.33 \mathrm{i}$ \\
\hline & 2000 & $48.83 \mathrm{i}$ & $41.82 \mathrm{i}$ & $44 \mathrm{~h}$ & $40 \mathrm{~g}$ & $2.23 \mathrm{~g}$ & $2.1 \mathrm{f}$ \\
\hline & $\mathbf{0}$ & $54.26 \mathrm{~h}$ & $53.72 \mathrm{~h}$ & $56 \mathrm{~g}$ & $42.67 \mathrm{~g}$ & $2.33 \mathrm{f}$ & $1.33 \mathrm{i}$ \\
\hline \multirow[t]{3}{*}{$\mathbf{S}+\mathbf{P}$} & 1000 & $71.47 \mathrm{e}$ & $66.51 \mathrm{e}$ & $57.33 \mathrm{~g}$ & $52.33 \mathrm{f}$ & $2.33 \mathrm{f}$ & $1.87 \mathrm{~g}$ \\
\hline & 2000 & $79 \mathrm{~d}$ & $69.97 \mathrm{~d}$ & $63.33 \mathrm{e}$ & $56.66 \mathrm{e}$ & $2.66 \mathrm{e}$ & $2.33 \mathrm{e}$ \\
\hline & $\mathbf{0}$ & $59.98 \mathrm{~g}$ & $57.69 \mathrm{~g}$ & $59.67 \mathrm{f}$ & $57.33 \mathrm{e}$ & $2.33 \mathrm{f}$ & $1.66 \mathrm{~h}$ \\
\hline \multirow[t]{3}{*}{ Char1 } & 1000 & $81.99 \mathrm{c}$ & $70.69 \mathrm{c}$ & $70 \mathrm{~d}$ & $62.66 \mathrm{~d}$ & $2.86 \mathrm{~d}$ & $2.66 \mathrm{~d}$ \\
\hline & 2000 & $81.43 \mathrm{c}$ & $77.63 \mathrm{~b}$ & $75.33 \mathrm{c}$ & $64.66 \mathrm{c}$ & $3.66 \mathrm{~b}$ & $3.33 \mathrm{~b}$ \\
\hline & $\mathbf{0}$ & $70.32 \mathrm{f}$ & $62.56 \mathrm{f}$ & $63 e$ & $57.33 \mathrm{e}$ & $2.66 \mathrm{e}$ & $2.33 \mathrm{e}$ \\
\hline \multirow[t]{3}{*}{ Char2 } & 1000 & $89.27 \mathrm{~b}$ & $77.93 \mathrm{~b}$ & $77.66 \mathrm{~b}$ & $74.33 \mathrm{~b}$ & $3.33 \mathrm{c}$ & $3.11 \mathrm{c}$ \\
\hline & 2000 & $91.51 \mathrm{a}$ & $89.94 \mathrm{a}$ & 2020 & $90.66 \mathrm{a}$ & $4.10 \mathrm{a}$ & $3.66 \mathrm{a}$ \\
\hline & $\mathbf{0}$ & $47.70 \mathrm{k}$ & $41.33 \mathrm{i}$ & $31.87 \mathrm{j}$ & $28.51 \mathrm{j}$ & $1.05 \mathrm{~h}$ & $1.02 \mathrm{~h}$ \\
\hline \multirow[t]{3}{*}{$\mathbf{S}$} & 1000 & $50.55 \mathrm{j}$ & $46.15 \mathrm{~h}$ & $36.65 \mathrm{i}$ & $33.76 \mathrm{i}$ & $2.15 \mathrm{~g}$ & $1.10 \mathrm{~h}$ \\
\hline & 2000 & $53.52 \mathrm{i}$ & $50.77 \mathrm{~g}$ & $46.65 \mathrm{~h}$ & $40.65 \mathrm{~h}$ & $2.49 \mathrm{f}$ & $2.49 \mathrm{e}$ \\
\hline & $\mathbf{0}$ & $66.62 \mathrm{~h}$ & $56.05 \mathrm{f}$ & $58.80 \mathrm{~g}$ & $44.8 \mathrm{~g}$ & $2.49 \mathrm{f}$ & $2.31 \mathrm{f}$ \\
\hline \multirow[t]{3}{*}{$\mathbf{S}+\mathbf{P}$} & 1000 & $74.67 \mathrm{f}$ & $69.48 \mathrm{~d}$ & $60.19 \mathrm{f}$ & $54.95 \mathrm{f}$ & $2.49 \mathrm{f}$ & $2.39 \mathrm{f}$ \\
\hline & 2000 & $82.56 \mathrm{~d}$ & $73.12 \mathrm{c}$ & $66.5 \mathrm{e}$ & $59.49 \mathrm{e}$ & $3.52 \mathrm{e}$ & $2.85 \mathrm{c}$ \\
\hline & $\mathbf{0}$ & $68.61 \mathrm{~g}$ & $60.22 \mathrm{e}$ & $61.60 \mathrm{ef}$ & $55.19 \mathrm{f}$ & $2.49 \mathrm{f}$ & $1.77 \mathrm{~g}$ \\
\hline \multirow[t]{3}{*}{ Char1 } & 1000 & $85.69 \mathrm{c}$ & $73.88 \mathrm{c}$ & $68.25 \mathrm{~d}$ & $65.79 \mathrm{c}$ & $2.85 \mathrm{~d}$ & $2.81 \mathrm{c}$ \\
\hline & 2000 & $85.13 c$ & $81.16 \mathrm{~b}$ & $72.75 \mathrm{c}$ & $67.89 \mathrm{c}$ & $3.50 \mathrm{c}$ & $2.85 \mathrm{c}$ \\
\hline & $\mathbf{0}$ & $77.19 \mathrm{e}$ & $72.22 \mathrm{c}$ & $66.15 \mathrm{e}$ & $60.19 \mathrm{~d}$ & $2.85 \mathrm{~d}$ & $2.51 \mathrm{~d}$ \\
\hline \multirow[t]{2}{*}{ Char2 } & 1000 & $93.35 \mathrm{~b}$ & $81.49 \mathrm{~b}$ & $81.54 \mathrm{~b}$ & $78.05 \mathrm{~b}$ & $3.61 \mathrm{~b}$ & $3.50 \mathrm{~b}$ \\
\hline & 2000 & $95.77 \mathrm{a}$ & $90.12 \mathrm{a}$ & $97.99 \mathrm{a}$ & $93.19 \mathrm{a}$ & $4.65 \mathrm{a}$ & $3.91 \mathrm{a}$ \\
\hline
\end{tabular}

S (sand), S+P (sand: peat moss 3:1 v/v), Char1 (sand: biochar 3:0.5 v/v) and Char2 (sand: biochar 3:1 v/v). Means followed by the same letter are not statistically different by Duncan at 0.05 levels.

the same line as well where proved that mixing cultural media such biochar, peat moss and compost improved cutting vegetative performance of different grapevine rootstocks (Salomé, et al. (2016); Bozzolo, et al. 2017). Also the results of this study agree with the findings of Abo-Ogiala (2018) on volkamer lemon seedlings in pots under salinity condition where he found that peat moss and biochar media were improved seedlings growth performance in comparison with sand alone under that condition. Farooq et al. (2018) found that mixing different cultural media with sand clearly induced cuttings growth of different grape rootstocks.

Also, the results agreed with Guo et al. (2018) who found that biochar substrate as propagation media improved Poinsettia seedling growth and development. Muhammad et al. (2018) also stated that sand media mixed with canal silt or bagasse or peat enhanced the vegetative growth of grape cuttings.

\subsection{Effect of IBA and cultural media on cutting root growth traits of Salt Creek grape rootstock 'Ramsey'}

Table (5) showed results of root parameters, i.e., number of root per cutting, root length and root thickness were of the interest. Results in Table (5) revealed that both IBA treatments improved cuttings root grown in all different cultural media in comparison that grown in sand media as control. Similar to the results obtained with cuttings vegetative growth traits, the intermediate cuttings treated with 2000 ppm IBA in Char2 were the best in the two seasons for all measured parameters. Same type cuttings treated with 1000 ppm IBA in Char2 came secondly as the best results in that concerns in the two seasons as well, (Table 5). 
Table 4. Effect of cultural media and IBA on shoot thickness (mm), number of leaves per shoot and leaf area $\left(\mathrm{cm}^{2}\right)$ for intermediate and basal stem cuttings of Ramsey grape rootstock during 2019 and 2020 growing seasons.

\begin{tabular}{|c|c|c|c|c|c|c|c|}
\hline \multirow{2}{*}{\multicolumn{2}{|c|}{ Treatments }} & \multicolumn{2}{|c|}{$\begin{array}{l}\text { Shoot thickness } \\
(\mathrm{mm})\end{array}$} & \multicolumn{2}{|c|}{$\begin{array}{c}\begin{array}{c}\text { Number of } \\
\text { leaves shoot }\end{array} \\
\end{array}$} & \multicolumn{2}{|c|}{$\begin{array}{c}\text { Leaf area } \\
\left(\mathrm{cm}^{2}\right)\end{array}$} \\
\hline & & Intermediate & basal & Intermediate & basal & Intermediate & basal \\
\hline \multirow[t]{2}{*}{ Media } & IBA (ppm) & \multicolumn{6}{|c|}{2019} \\
\hline & $\mathbf{0}$ & $1.11 \mathrm{j}$ & $1.01 \mathrm{j}$ & $12.66 \mathrm{k}$ & $10.33 \mathrm{i}$ & $80.37 \mathrm{i}$ & $73.78 \mathrm{i}$ \\
\hline \multirow[t]{3}{*}{$\mathbf{S}$} & 1000 & $1.71 \mathrm{i}$ & $1.19 \mathrm{i}$ & $15.66 \mathrm{j}$ & $13.66 \mathrm{~h}$ & $85.66 \mathrm{hi}$ & $80.34 \mathrm{hi}$ \\
\hline & 2000 & $2.24 \mathrm{f}$ & $2.14 \mathrm{e}$ & $18.66 \mathrm{i}$ & $16.66 \mathrm{gh}$ & $93.71 \mathrm{~h}$ & $89.92 \mathrm{~h}$ \\
\hline & $\mathbf{0}$ & $1.96 \mathrm{~h}$ & $1.76 \mathrm{~g}$ & $21 \mathrm{~h}$ & $19.33 \mathrm{~g}$ & $111.41 \mathrm{~g}$ & $99.80 \mathrm{~g}$ \\
\hline \multirow[t]{3}{*}{$\mathbf{S}+\mathbf{P}$} & 1000 & $2.17 \mathrm{~g}$ & $2.01 \mathrm{f}$ & $28.33 \mathrm{~g}$ & $24.33 \mathrm{f}$ & $135.27 \mathrm{f}$ & $132.42 \mathrm{f}$ \\
\hline & 2000 & $2.46 \mathrm{~d}$ & $2.08 \mathrm{ef}$ & $33.66 f$ & $29.54 \mathrm{e}$ & $141.71 \mathrm{e}$ & 136.4 ef \\
\hline & $\mathbf{0}$ & $2.17 \mathrm{~g}$ & $1.55 \mathrm{~h}$ & $34.33 \mathrm{e}$ & $30 \mathrm{~d}$ & $144.53 \mathrm{~d}$ & $140.04 \mathrm{e}$ \\
\hline \multirow[t]{3}{*}{ Char1 } & 1000 & $2.63 \mathrm{c}$ & $2.43 \mathrm{~d}$ & $37 \mathrm{~cd}$ & $33.33 \mathrm{~cd}$ & $157.76 \mathrm{c}$ & $152.84 \mathrm{~d}$ \\
\hline & 2000 & $2.86 \mathrm{~b}$ & $2.58 \mathrm{c}$ & $38.33 \mathrm{c}$ & $34 \mathrm{c}$ & $162.16 \mathrm{bc}$ & $159.14 \mathrm{c}$ \\
\hline & $\mathbf{0}$ & $2.39 \mathrm{e}$ & $2.09 \mathrm{e}$ & $36 \mathrm{~d}$ & $30.66 \mathrm{~d}$ & $161.56 \mathrm{bc}$ & $159.08 \mathrm{c}$ \\
\hline \multirow[t]{4}{*}{ Char2 } & 1000 & $2.86 \mathrm{~b}$ & $2.76 \mathrm{~b}$ & $40 \mathrm{~b}$ & $39 \mathrm{~b}$ & $169.82 \mathrm{~b}$ & $164.19 \mathrm{~b}$ \\
\hline & 2000 & $3.19 \mathrm{a}$ & $2.92 \mathrm{a}$ & $42.33 \mathrm{a}$ & $41.66 \mathrm{a}$ & $178.21 \mathrm{a}$ & $175.39 \mathrm{a}$ \\
\hline & & \multicolumn{6}{|c|}{2020} \\
\hline & $\mathbf{0}$ & $1.40 \mathrm{k}$ & $1.30 \mathrm{j}$ & $14.44 \mathrm{j}$ & $12.10 \mathrm{i}$ & $118.13 \mathrm{k}$ & $115.49 \mathrm{i}$ \\
\hline \multirow[t]{3}{*}{$\mathbf{S}$} & 1000 & $1.65 \mathrm{j}$ & $1.55 \mathrm{i}$ & $15.09 \mathrm{ij}$ & 14.49hi & $126.68 \mathrm{j}$ & $122.04 \mathrm{hi}$ \\
\hline & 2000 & $1.77 \mathrm{j}$ & $1.57 \mathrm{hi}$ & $17.34 \mathrm{i}$ & $16.39 \mathrm{~h}$ & $130.78 \mathrm{i}$ & $123.20 \mathrm{~h}$ \\
\hline & 0 & $1.48 \mathrm{i}$ & $1.38 \mathrm{ij}$ & $22.05 \mathrm{~h}$ & $19.4 \mathrm{~g}$ & $137.83 \mathrm{~h}$ & $132.30 \mathrm{~g}$ \\
\hline \multirow[t]{3}{*}{$\mathbf{S}+\mathbf{P}$} & 1000 & $1.68 \mathrm{~h}$ & $1.6 \mathrm{~h}$ & $23.75 \mathrm{gh}$ & $20.50 \mathrm{f}$ & $140.25 \mathrm{~g}$ & $132.56 \mathrm{~g}$ \\
\hline & 2000 & $1.88 \mathrm{~g}$ & $1.73 \mathrm{~g}$ & $25.34 \mathrm{~g}$ & 22 ef & $148.78 \mathrm{f}$ & $143.82 \mathrm{f}$ \\
\hline & 0 & $2.28 \mathrm{f}$ & $2.12 \mathrm{f}$ & $30.05 \mathrm{f}$ & $28.2 \mathrm{e}$ & $151.77 \mathrm{e}$ & $143.09 \mathrm{f}$ \\
\hline \multirow[t]{3}{*}{ Char1 } & 1000 & $2.76 \mathrm{~d}$ & $2.56 \mathrm{~d}$ & $35.59 \mathrm{e}$ & $34.6 \mathrm{~d}$ & $160.88 \mathrm{~d}$ & $154.40 \mathrm{e}$ \\
\hline & 2000 & $3 c$ & $2.76 \mathrm{c}$ & $39.19 \mathrm{c}$ & $35.70 \mathrm{c}$ & $164.99 \mathrm{~cd}$ & $150.3 \mathrm{~d}$ \\
\hline & $\mathbf{0}$ & $2.51 \mathrm{e}$ & $2.20 \mathrm{e}$ & $37.8 \mathrm{~d}$ & $35.19 \mathrm{c}$ & $169.14 \mathrm{c}$ & $160.52 \mathrm{c}$ \\
\hline \multirow[t]{2}{*}{ Char2 } & 1000 & $3.27 \mathrm{~b}$ & $3.07 \mathrm{~b}$ & $42.1 \mathrm{~b}$ & $40.95 \mathrm{~b}$ & $172.4 \mathrm{~b}$ & $165.66 \mathrm{~b}$ \\
\hline & 2000 & $3.35 \mathrm{a}$ & $3.16 \mathrm{a}$ & $44.45 \mathrm{a}$ & $43.74 \mathrm{a}$ & $184.15 \mathrm{a}$ & $180.13 \mathrm{a}$ \\
\hline
\end{tabular}

S (sand), S+P (sand: peat moss 3:1 v/v), Char1 (sand: biochar 3:0.5 v/v) and Char2 (sand: biochar 3:1 v/v). Means followed by the same letter are not statistically different by Duncan at 0.05 levels.

The basal cuttings treated with 2000 ppm IBA and grown in Char2 came thirdly then followed by intermediate cuttings treated with 2000 ppm IBA and grown in Char1(Table 5). IBA at $1000 \mathrm{ppm}$ in Char1 with intermediate cuttings showed the fifth good results for all studied parameters.

Treating basal cuttings with 2000 ppm IBA in Char2 came afterwards followed by intermediate cuttings treated with 2000 ppm IBA grown in the mixture media of sand: peat moss. Then the intermediate cuttings treated with $1000 \mathrm{ppm}$ IBA in the media of sand: peat moss. In the absence of IBA treatments, the intermediate cuttings grown in Char2 were the next followed by the intermediate cuttings grown in Char1without IBA treatments. Afterwards, basal cuttings grown in Char2 without IBA treatments were the following. Then, the basal cuttings grown in Char1 without IBA treatments followed by intermediate cuttings treated with 2000 ppm IBA and grown in sand alone. Finally the intermediate cuttings treated with 1000 ppm IBA and grown in sand alone

The results came in agreements with Satisha and Adsule (2008); Galavi et al. (2013) and FlorezSarasa et al. (2020) who reported that different IBA concentrations induced cutting root formation with enhancing root length and width of different grape rootstocks.

Moreover, the results of this study came in the same line with İsfendiyaroğlu et al., (2009) and Sengel et al., (2012) whom reported that mixing cultural rooting media with sand enhanced roots sprouting on cuttings as well as root length and root width. In the same line, other study proved that biochar, peat moss and compost as an alternative of sand as propagation media were improved root formation, i.e., number of root per cutting, root length and root thickness for different grapevine rootstocks (Salomé, et al. (2016); Bozzolo, et al. 2017. Abo-Ogiala (2018) confirmed that biochar media as alternative of perlite with the mixture 
Table 5. Effect of cultural media and IBA on number of roots per cutting, root length $(\mathrm{cm})$ and root thickness $(\mathrm{mm})$ for intermediate and basal stem cuttings of Ramsey grape rootstock during 2019 and 2020 growing seasons.

\begin{tabular}{|c|c|c|c|c|c|c|c|}
\hline \multirow{2}{*}{\multicolumn{2}{|c|}{ Treatments }} & \multicolumn{2}{|c|}{ Root number/cutting } & \multicolumn{2}{|c|}{ Root length(cm) } & \multicolumn{2}{|c|}{ roots thickness (mm) } \\
\hline & & Intermediate & basal & Intermediate & basal & Intermediate & Basal \\
\hline \multirow[t]{2}{*}{ Media } & IBA (ppm) & \multicolumn{6}{|c|}{2019} \\
\hline & $\mathbf{0}$ & $3.66 \mathrm{i}$ & $3.66 \mathrm{~g}$ & $33.33 \mathrm{~g}$ & $32 \mathrm{de}$ & $0.51 \mathrm{~h}$ & $0.46 \mathrm{~h}$ \\
\hline \multirow[t]{3}{*}{$\mathbf{S}$} & 1000 & $7.66 \mathrm{~h}$ & $5.67 \mathrm{fg}$ & $35.66 \mathrm{f}$ & $33 \mathrm{~d}$ & $0.62 \mathrm{gh}$ & $0.55 \mathrm{gh}$ \\
\hline & 2000 & $8.33 \mathrm{~g}$ & $6.66 \mathrm{f}$ & $38.66 \mathrm{e}$ & $37.66 \mathrm{bc}$ & $0.73 \mathrm{~g}$ & $0.62 \mathrm{gh}$ \\
\hline & $\mathbf{0}$ & $8.01 \mathrm{~g}$ & $6.66 \mathrm{f}$ & $35.33 \mathrm{f}$ & $29.54 \mathrm{f}$ & $0.93 \mathrm{f}$ & $0.73 \mathrm{~g}$ \\
\hline \multirow[t]{3}{*}{$\mathbf{S}+\mathbf{P}$} & 1000 & $14.66 \mathrm{e}$ & $11.66 \mathrm{e}$ & $38.33 \mathrm{e}$ & $30.66 \mathrm{e}$ & 1.09 ef & $1.02 \mathrm{f}$ \\
\hline & 2000 & $15.66 \mathrm{de}$ & $13 \mathrm{~d}$ & $40.33 \mathrm{~d}$ & $32.66 \mathrm{de}$ & $1.14 \mathrm{e}$ & $1.04 \mathrm{ef}$ \\
\hline & $\mathbf{0}$ & $13.33 \mathrm{f}$ & $12.33 \mathrm{de}$ & 37 ef & $32.67 \mathrm{de}$ & $1.27 \mathrm{~cd}$ & $1.16 \mathrm{~d}$ \\
\hline \multirow[t]{3}{*}{ Char1 } & 1000 & $20.33 \mathrm{c}$ & $15 \mathrm{c}$ & $41 \mathrm{~cd}$ & $34.66 \mathrm{~d}$ & $1.37 \mathrm{c}$ & $1.25 \mathrm{~cd}$ \\
\hline & 2000 & $22.33 \mathrm{~b}$ & $18.3 \mathrm{~b} 3$ & $45.33 \mathrm{c}$ & $40.33 \mathrm{bc}$ & $1.45 \mathrm{~b}$ & $1.3 \mathrm{c}$ \\
\hline & $\mathbf{0}$ & $16.66 \mathrm{~d}$ & $13.32 \mathrm{~d}$ & $38.66 \mathrm{e}$ & $36.33 c$ & $1.21 \mathrm{~d}$ & $1.11 \mathrm{e}$ \\
\hline \multirow[t]{3}{*}{ Char2 } & 1000 & $21.66 \mathrm{bc}$ & $17.66 \mathrm{bc}$ & $53 \mathrm{~b}$ & $41.66 \mathrm{~b}$ & $1.58 \mathrm{ab}$ & $1.52 \mathrm{~b}$ \\
\hline & 2000 & $27.33 \mathrm{a}$ & $22.66 \mathrm{a}$ & $\begin{array}{l}57.33 \mathrm{a} \\
\mathbf{2 0 2 0}\end{array}$ & $47.33 \mathrm{a}$ & $1.66 \mathrm{a}$ & $1.61 \mathrm{a}$ \\
\hline & $\mathbf{0}$ & $3.84 \mathrm{j}$ & $3.84 \mathrm{~h}$ & $27.99 \mathrm{~g}$ & $22.60 \mathrm{~h}$ & $0.85 \mathrm{~g}$ & $0.74 \mathrm{~h}$ \\
\hline \multirow[t]{3}{*}{$\mathbf{S}$} & 1000 & $5.04 \mathrm{i}$ & $4.6 \mathrm{~g}$ & $30.64 \mathrm{fg}$ & $25.10 \mathrm{~g}$ & $0.94 \mathrm{fg}$ & $0.84 \mathrm{gh}$ \\
\hline & 2000 & $8.75 \mathrm{~h}$ & $5.39 \mathrm{fg}$ & $34.59 \mathrm{f}$ & $32.54 \mathrm{f}$ & $1.11 \mathrm{f}$ & $0.95 \mathrm{~g}$ \\
\hline & $\mathbf{0}$ & $10.27 \mathrm{~g}$ & $6.99 \mathrm{f}$ & $37.09 \mathrm{e}$ & $35.70 \mathrm{de}$ & $1.18 \mathrm{ef}$ & $1.15 \mathrm{f}$ \\
\hline \multirow[t]{3}{*}{$\mathbf{S}+\mathbf{P}$} & 1000 & $15.39 \mathrm{f}$ & $13.39 \mathrm{de}$ & $40.25 \mathrm{~d}$ & $34.79 \mathrm{e}$ & $1.26 \mathrm{e}$ & $1.22 \mathrm{e}$ \\
\hline & 2000 & 16.44 ef & $14.85 \mathrm{de}$ & $42.35 \mathrm{~cd}$ & $40.99 \mathrm{c}$ & $1.34 \mathrm{~d}$ & $1.32 \mathrm{ed}$ \\
\hline & 0 & $17.69 \mathrm{e}$ & $12.95 \mathrm{e}$ & $38.85 \mathrm{de}$ & $36.75 \mathrm{de}$ & $1.40 \mathrm{~cd}$ & $1.38 \mathrm{~cd}$ \\
\hline \multirow[t]{3}{*}{ Char1 } & 1000 & $21.09 \mathrm{c}$ & $15.75 \mathrm{~d}$ & $43.05 \mathrm{c}$ & $40.29 \mathrm{c}$ & $1.46 \mathrm{c}$ & $1.45 \mathrm{c}$ \\
\hline & 2000 & $23.45 \mathrm{~b}$ & $19.25 \mathrm{bc}$ & $53.35 \mathrm{bc}$ & $47.65 \mathrm{ab}$ & $1.63 \mathrm{~b}$ & $1.59 \mathrm{~b}$ \\
\hline & 0 & $20.24 \mathrm{~d}$ & $18.50 \mathrm{c}$ & $40.59 \mathrm{~d}$ & $38.15 \mathrm{~d}$ & $1.35 \mathrm{~d}$ & $1.3 \mathrm{~d}$ \\
\hline \multirow[t]{2}{*}{ Char2 } & 1000 & $22.74 \mathrm{bc}$ & $20.74 \mathrm{~b}$ & $55.65 \mathrm{~b}$ & $45.65 \mathrm{~b}$ & $1.64 \mathrm{ab}$ & $1.60 \mathrm{ab}$ \\
\hline & 2000 & $28.69 \mathrm{a}$ & $23.79 \mathrm{a}$ & $60.2 \mathrm{a}$ & $50.20 \mathrm{a}$ & $1.74 \mathrm{a}$ & $1.70 \mathrm{a}$ \\
\hline
\end{tabular}

S (sand), S+P (sand: peat moss 3:1 v/v), Char1 (sand: biochar 3:0.5 v/v) and Char2 (sand: biochar 3:1 v/v). Means followed by the same letter are not statistically different by Duncan at 0.05 levels.

media of sand and peat moss were improved the root fresh and dry weight of volkamer lemon seedlings grown in pots under salinity condition. Furthermore, Farooq et al. (2018) reported that various cultural media that mixed with sand were behind the induction of root formation of different grape rootstocks cuttings. Coming more closer, Guo et al. (2018) found that wood biochar as mixing substrate with sand media enhanced the propagation of Poinsettia seedless especially at the root level formation, i.e., fresh and dry root weight. In addition, Muhammad et al. (2018) showed that mixing different cultural media, i.e., canal silt or bagasse or peat moss with sand enhanced the vegetative growth of grape cuttings.

\subsection{Effect of IBA and cultural media on the nutrient leave content of Salt Creek grape rootstock 'Ramsey' cuttings}

Results in Table (6) confirmed that both IBA treatments were increased the uptake of $\mathrm{N}, \mathrm{P}$,
$\mathrm{K}, \mathrm{Ca}$, and $\mathrm{Mg}$ by cuttings grown in the cultural media mixed with peat moss or bichar in comparison with that grown in sand media as control. The results take the similar direction to that obtained with cuttings vegetative or root traits. Intermediate cuttings treated with 2000 ppm IBA and cultivated in Char2 showed the highest nutrient uptake in the two seasons, (Table 6). Also, same type cuttings dipped in 1000 ppm IBA and cultivated in Char2 came secondly as the highest results in that concerns in the two seasons as well, (Table 6). The rest of results concerning the nutrient uptake in the different treatments can be arranged as followed and mentioned with cuttings vegetative or root traits without repetition and easily can be reached from Table (6).

The results of this work agree with Muhammad (2005) and Waite et al., (2015) whom found that intermediate cuttings were superior to basal cuttings in the ability of nutrient uptake in different grape rootstocks. Other results also come in 
Scientific Journal of Agricultural Sciences 3 (2): 58-67, 2021

Table 6. Effect of cultural media and IBA on leaves contents of N, P, K, Ca and Mg of intermediate and basal stem cuttings of Ramsey grape rootstock during 2019 and 2020 growing seasons.

\begin{tabular}{|c|c|c|c|c|c|c|c|c|c|c|c|}
\hline \multirow{2}{*}{\multicolumn{2}{|c|}{ Treatments }} & \multicolumn{2}{|l|}{$\mathbf{N} \%$} & \multicolumn{2}{|l|}{ P \% } & \multicolumn{2}{|l|}{ K \% } & \multicolumn{2}{|l|}{$\mathrm{Ca} \%$} & \multicolumn{2}{|c|}{ Mg \% } \\
\hline & & Intermediate & basal & Intermediate & basal & Intermediate & basal & Intermediate & basal & Intermediate & basal \\
\hline Media & IBA ppm & \multicolumn{10}{|c|}{2019} \\
\hline \multirow{4}{*}{$\mathbf{S}$} & $\mathbf{0}$ & $1.02 \mathrm{~h}$ & $1.01 \mathrm{~g}$ & $0.31 \mathrm{~h}$ & $0.27 \mathrm{~h}$ & $1.30 \mathrm{e}$ & $1.24 \mathrm{i}$ & $1.21 \mathrm{i}$ & $1.13 \mathrm{i}$ & $3.12 \mathrm{i}$ & $3.05 \mathrm{~h}$ \\
\hline & 1000 & $1.04 \mathrm{gh}$ & $1.03 \mathrm{fg}$ & $0.34 \mathrm{~g}$ & $0.30 \mathrm{~g}$ & $1.37 \mathrm{de}$ & $1.32 \mathrm{~h}$ & $1.26 \mathrm{~h}$ & 1.17hi & $3.22 \mathrm{hi}$ & $3.15 \mathrm{gh}$ \\
\hline & 2000 & $1.11 \mathrm{gh}$ & $1.09 \mathrm{f}$ & $0.36 \mathrm{ef}$ & $0.33 \mathrm{fg}$ & $1.41 \mathrm{~d}$ & $1.36 \mathrm{gh}$ & $1.31 \mathrm{gh}$ & $1.23 \mathrm{~h}$ & $3.35 \mathrm{~h}$ & $3.26 \mathrm{~g}$ \\
\hline & $\mathbf{0}$ & $1.16 \mathrm{~g}$ & $1.14 \mathrm{e}$ & $0.34 \mathrm{f}$ & $0.34 \mathrm{~g}$ & $1.51 \mathrm{~cd}$ & $1.46 \mathrm{~g}$ & $1.38 \mathrm{~g}$ & $1.32 \mathrm{~g}$ & $3.57 \mathrm{fg}$ & $3.46 \mathrm{f}$ \\
\hline \multirow[t]{3}{*}{$\mathbf{S}+\mathbf{P}$} & 1000 & $1.29 \mathrm{f}$ & $1.24 \mathrm{de}$ & 0.36 ef & $0.42 \mathrm{f}$ & $1.64 \mathrm{c}$ & $1.60 \mathrm{f}$ & $1.41 \mathrm{f}$ & $1.35 \mathrm{fg}$ & $3.75 \mathrm{f}$ & $3.64 \mathrm{e}$ \\
\hline & 2000 & $1.32 \mathrm{e}$ & $1.28 \mathrm{~d}$ & $0.39 \mathrm{e}$ & $0.46 \mathrm{e}$ & $1.73 \mathrm{~b}$ & $1.69 \mathrm{e}$ & $1.46 \mathrm{ef}$ & $1.43 \mathrm{e}$ & $3.87 \mathrm{e}$ & $3.75 \mathrm{de}$ \\
\hline & 0 & $1.39 \mathrm{de}$ & $1.36 \mathrm{~d}$ & $0.40 \mathrm{~d}$ & $0.37 \mathrm{de}$ & $1.64 \mathrm{c}$ & $1.61 \mathrm{~d}$ & $1.47 \mathrm{e}$ & $1.37 \mathrm{f}$ & $4.01 \mathrm{de}$ & $3.75 \mathrm{de}$ \\
\hline \multirow[t]{3}{*}{ Char1 } & 1000 & $1.45 \mathrm{~d}$ & $1.41 \mathrm{bc}$ & $0.42 \mathrm{~cd}$ & $0.41 \mathrm{~d}$ & $1.72 \mathrm{~b}$ & $1.67 \mathrm{c}$ & $1.52 \mathrm{~d}$ & $1.43 \mathrm{e}$ & $4.11 \mathrm{~d}$ & $3.86 \mathrm{~d}$ \\
\hline & 2000 & $1.54 \mathrm{~b}$ & $1.5 \mathrm{ab}$ & $0.44 \mathrm{c}$ & $0.48 \mathrm{bc}$ & $1.86 \mathrm{ab}$ & $1.82 \mathrm{ab}$ & $1.59 \mathrm{~cd}$ & $1.53 \mathrm{~d}$ & $4.25 \mathrm{c}$ & $4.17 \mathrm{c}$ \\
\hline & $\mathbf{0}$ & $1.44 \mathrm{~cd}$ & $1.40 \mathrm{c}$ & $0.50 \mathrm{~b}$ & $0.47 \mathrm{c}$ & $1.72 \mathrm{~b}$ & $1.70 \mathrm{~b}$ & $1.6 \mathrm{c}$ & $1.65 \mathrm{c}$ & $4.32 \mathrm{bc}$ & $4.25 \mathrm{bc}$ \\
\hline \multirow[t]{3}{*}{ Char2 } & 1000 & $1.48 \mathrm{c}$ & $1.46 \mathrm{~b}$ & $0.55 \mathrm{ab}$ & $0.52 \mathrm{~b}$ & $1.84 \mathrm{ab}$ & $1.81 \mathrm{ab}$ & $1.8 \mathrm{~b}$ & $1.75 \mathrm{~b}$ & $4.67 \mathrm{~b}$ & $4.56 \mathrm{~b}$ \\
\hline & 2000 & $1.61 \mathrm{a}$ & \multicolumn{8}{|c|}{2020} & $5.47 \mathrm{a}$ \\
\hline & $\mathbf{0}$ & $1.04 \mathrm{~h}$ & $1.01 \mathrm{~g}$ & $0.30 \mathrm{f}$ & $0.26 \mathrm{i}$ & $1.32 \mathrm{~g}$ & $1.26 \mathrm{~h}$ & $1.17 \mathrm{~g}$ & $1.13 \mathrm{i}$ & $3.05 \mathrm{~g}$ & $3.01 \mathrm{~h}$ \\
\hline \multirow[t]{3}{*}{$\mathbf{S}$} & 1000 & $1.12 \mathrm{gh}$ & $1.03 \mathrm{fg}$ & $0.31 \mathrm{ef}$ & $0.29 \mathrm{hi}$ & $1.37 \mathrm{fg}$ & $1.32 \mathrm{gh}$ & $1.24 \mathrm{fg}$ & $1.19 \mathrm{hi}$ & $3.17 \mathrm{fg}$ & $3.10 \mathrm{gh}$ \\
\hline & 2000 & $1.2 \mathrm{~g}$ & $1.11 \mathrm{f}$ & 0.34 ef & $0.31 \mathrm{~h}$ & $1.47 \mathrm{f}$ & $1.47 \mathrm{~g}$ & $1.26 \mathrm{f}$ & $1.25 \mathrm{~h}$ & $3.25 \mathrm{f}$ & $3.17 \mathrm{~g}$ \\
\hline & $\mathbf{0}$ & $1.31 \mathrm{f}$ & $1.28 \mathrm{e}$ & $0.37 \mathrm{e}$ & $0.34 \mathrm{~g}$ & $1.54 \mathrm{e}$ & $1.50 \mathrm{f}$ & $1.47 \mathrm{e}$ & $1.42 \mathrm{~g}$ & $3.56 \mathrm{e}$ & $3.52 \mathrm{f}$ \\
\hline \multirow[t]{3}{*}{$\mathbf{S}+\mathbf{P}$} & 1000 & $1.43 \mathrm{e}$ & $1.37 \mathrm{de}$ & $0.41 \mathrm{~d}$ & $0.38 \mathrm{f}$ & $1.65 \mathrm{de}$ & $1.61 \mathrm{e}$ & $1.52 \mathrm{de}$ & $1.47 \mathrm{f}$ & $3.74 \mathrm{de}$ & 3.64 ef \\
\hline & 2000 & $1.5 \mathrm{~d}$ & $1.47 \mathrm{~cd}$ & $0.47 \mathrm{~cd}$ & $0.44 \mathrm{e}$ & $1.75 \mathrm{c}$ & $1.73 \mathrm{~cd}$ & $1.57 \mathrm{~d}$ & $1.56 \mathrm{e}$ & $3.94 \mathrm{~d}$ & $3.85 \mathrm{e}$ \\
\hline & $\mathbf{0}$ & $1.42 \mathrm{ef}$ & $1.39 \mathrm{~d}$ & $0.51 \mathrm{~b}$ & $0.46 \mathrm{de}$ & $1.67 \mathrm{~d}$ & $1.63 \mathrm{de}$ & $1.68 \mathrm{c}$ & $1.61 \mathrm{de}$ & $4.32 \mathrm{c}$ & $4.26 \mathrm{~d}$ \\
\hline \multirow[t]{3}{*}{ Char1 } & 1000 & $1.55 \mathrm{c}$ & $1.47 \mathrm{~cd}$ & $0.49 \mathrm{c}$ & $0.47 \mathrm{~d}$ & $1.71 \mathrm{c}$ & $1.68 \mathrm{~d}$ & $1.71 \mathrm{bc}$ & $1.67 \mathrm{~d}$ & $4.48 \mathrm{bc}$ & $4.36 \mathrm{~cd}$ \\
\hline & 2000 & $1.60 \mathrm{~b}$ & $1.53 \mathrm{~b}$ & $0.55 a b$ & $0.53 \mathrm{bc}$ & $1.86 \mathrm{ab}$ & $1.84 \mathrm{~b}$ & $1.74 b c$ & $1.70 \mathrm{~cd}$ & $4.53 b$ & $4.46 \mathrm{~cd}$ \\
\hline & 0 & $1.52 \mathrm{~cd}$ & $1.48 \mathrm{c}$ & $0.51 \mathrm{~b}$ & $0.50 \mathrm{c}$ & $1.77 \mathrm{~b}$ & $1.74 \mathrm{c}$ & $1.79 \mathrm{~b}$ & $1.74 \mathrm{c}$ & $4.65 \mathrm{bc}$ & $4.61 \mathrm{c}$ \\
\hline \multirow[t]{2}{*}{ Char2 } & 1000 & $1.60 \mathrm{~b}$ & $1.56 \mathrm{ab}$ & $0.57 \mathrm{ab}$ & $0.54 \mathrm{~b}$ & $1.87 \mathrm{ab}$ & $1.86 \mathrm{ab}$ & $1.85 \mathrm{ab}$ & $1.81 \mathrm{~b}$ & $4.76 \mathrm{a}$ & $4.70 \mathrm{~b}$ \\
\hline & 2000 & $1.66 \mathrm{a}$ & $1.63 \mathrm{a}$ & $0.58 \mathrm{a}$ & $0.56 \mathrm{a}$ & $1.91 \mathrm{a}$ & $1.87 \mathrm{a}$ & $1.95 \mathrm{a}$ & $1.92 \mathrm{a}$ & $5.43 \mathrm{bc}$ & $5.35 \mathrm{a}$ \\
\hline
\end{tabular}

Duncan at 0.05 levels. 
Abo- Ogiala A.M. et al., 2021

agreements with this study concerning IBA treatments where Florez-Sarasa et al. (2020) reported that IBA treatments improved nutrient uptake in different grape rootstocks as well.

Concerning cultural media the study came in agreements with Salomé, et al. (2016) and Bozzolo, et al. (2017) whom reported that mixing media cultivation with biochar, peat moss and compost improved and maintained soil fertility subsequently grapevine nutrient uptake. Furthermore, Farooq, et al. (2018) found that different cultural media that mixed with sand were increased nutrient leave uptake in different grape rootstocks cuttings.

\section{SUMMARY}

The aim of the study was focusing on improving the growth and nutrient uptake of Salt Creek grape rootstock 'Ramsey' cuttings that have rooting difficulties as promising rootstock for grape production in a climatic conditions that restrict and inhibit agriculture in general. For that purpose, designing an experiment in a randomized completely with 3 replicates for each treatment and each replicate included ten cutting was arranged. The experiment included 24 treatments as following: 2 types of cutting, i.e., intermediate and basal X 3 IBA treatments, i.e., 0,1000 and $2000 \times 4$ different rooting media, i.e., sand (S), sand: peat moss $3: 1 \mathrm{v} / \mathrm{v}$ $(\mathrm{S}+\mathrm{P})$, sand: biochar 3:0.5 v/v (Char1) and sand: bichar 3:1 v/v ( Char2)

Regarding to two type cuttings, the intermediate stem cutting showed the better results in all studied parameter under investigation as response to IBA treatments and cultural media tested. The treatment of 2000 ppm IBA with cultivation in Char2 gave the highest values, followed by 1000 ppm IBA in Char2. The following good results were obtained with cultivation in Char 1 with the same arrangement concentrations of IBA for both type cuttings. Afterwards came the results of $\mathrm{S}+\mathrm{P}$ treatments after IBA treatments descending. The lowest values obtained from both type cuttings cultivated in sand, however IBA treatments showed positive effects than the free of it in that media.

\section{CONCLUSION}

Results of the study recommended that both IBA treatments with Char2 as cultivation media to overcome the propagation problems that face Salt Creek grape rootstock 'Ramsey' cuttings. The results highlighted intermediate cuttings type for its superior response on basal cuttings in that concern.

\section{REFRENCES}

Abo-Ogiala AMME (2018). Impact of Biochar on Growth, Biochemical Parameters and Nutrients Content of Volkamer Lemon (C. volkameriana,
Tenx pasq.) under Saline Condition. Egyptian Journal of Horticulture, 45(2), 305-314.

Ahmed MK, Mokhtar M (2011). Why some grapevine cultivars are hard to root? Australian Journal of Basic and Applied Sciences, 5(2): 110116.

Bozzolo A, Pizzeghello D, Cardinali A, Francioso O (2017). Nardi, S. Effects of moderate and high rates of biochar and compost on grapevine growth in a greenhouse experiment.AIMS Agric. Food, 2, 113-128.

Bremner JM, Keeney DR (1965). Total nitrogen. Method of soil analysis, part2, pp 1149-1178. Agron Monogr 9.ASA Madison, WI. Black CA (ed).Chapman, H.D. and P.F. Pratt, 1961. Methods of Analysis for Soils, Plants and Waters Div. Agric. Sci. Univ. Calif. USA, pp, 309.

Cottenie A, Verloo M, Kiekens L, Velgle G, amerlynuck R (1982). Chemical Analysis of Plant and Soil, 43- 51. Laboratory of Analytical and Agroch. State Univ. of Belgium,Gent.

De Klerk GJ, Van Der Krieken W, De Jong JC (1999). Review - The formation of adventitious roots: new concepts, new possibilities. In vitro Cellular and Devolopmental Biology-Plant, 35:189199.

Epstein, E. and Müller, L. J. (1993). Indole-3butyric acid in plants: Occurrence, synthesis, metabolism and transport, Minireview, Physiologia Plantarum, 88: 382-389.

Farooq M, Kakar K, Golly MK, Ilyas N, Zib B, Khan S (2018). Comparative Effect of Potting Media on Sprouting and Seedling Growth of Grape Cuttings International Journal of Environmental and Agriculture Research;4(3)

Florez-Sarasa I, Clemente-Moreno MJ, Cifre J, Capó M, Llompart M, Fernie AR, Bota J (2020). Differences in Metabolic and Physiological Responses between Local and Widespread Grapevine Cultivars under Water Deficit Stress. Agronomy, 10(7), 1052.

Galavi M, Karimian MA, Mousavi SR (2013). Effects of different auxin (IBA) concentrations and planting-beds on rooting grape cuttings (Vitis vinifera). Annual Research \& Review in Biology: 517-523.

Gomez KA, Gomez AA (1984). Statistical procedures for agricultural research. John Wiley \& Sons.

Guo Y, Niu G, Starman T, Volder A, Gu M (2018). Poinsettia growth and development response to container root substrate with biochar. Horticulture; 4(1):1.

Hartmann HT, Kester DE, Davies FT, Geneve RL (2002). Plant Propagation, Principles and Practices, 7th Ed., Prentice Hall Inc., New Jersey, p.880. 
Howell GS (1987). Vitis rootstocks. In: Rootstocks for Fruit Crops. (Eds: R.C. Rom and R.F. Carlson), John Wiley \& Sons, Inc. USA, pp. 451-472.

İsfendiyaroğlu $M$, Özeker $E$, Başer S (2009). Rooting of 'Ayvalik' olive cuttings in different media, Spanish Journal of Agricultural Research, 7 (1): 165- 172.

Jackson ML (1967). Soil Chemical Analysis. Printice-Hall Inc. Englewood Cliffs-N.S. 6th ed

Lehmann J, Joseph S (2009). Biochar for environmental management: science and technology. Earthscan, London.

Migicovsky Z, Cousins P, Jordan LM, Myles S, Striegler RK, Verdegaal P, Chitwood DH (2021). Grapevine rootstocks affect growth related scion phenotypes. Plant direct, 5(5), p.e00324.

Muhammad F, Kaleem K, Moses KG, Naila I, Bakhshah Z (2018). Comparative Effect of Potting Media on Sprouting and Seedling Growth of Grape Cuttings. International Journal of Environmental \& Agriculture Research (IJOEAR) 4: 2454-1850.

Muhammad AMA (2005). Rooting of grape (Vitis vinifera ) cuttings in response to position and application of rooting hormone (IBA). M.Sc. Department of Horticulture, Faculty of Agriculture University of Khartoum.

Page AL (1982). Method of Soil Analysis, Part 2, Chemical and Microbiological Properties, Second edition, American Society of Agronomy, Inc and Soil Science Society of America, Inc. Publisher, Madison, Wisconsin USA.

Pratt P, Chapman H (1961). Gains and losses of mineral elements in an irrigated soil during a 20year lysimeter investigation. Hilgardia, 30(16), 445467.

Rieger M (2006). Introduction to Fruit Crops, Haworth Press Inc., Binghamton, NY, p. 462.

Salomé C, Coll P, Lardo E, Metay A (2016). The soil quality concept as a framework to assess management practices in vulnerable agroecosystems: A case study in Mediterranean vineyards. Ecol. Indic., 61, 456-465.

Satisha J, Adsule PG (2008). Rooting behavior of grape rootstocks in relation to IBA concentration and biochemical constituents of mother vines.Acta Horticulturae, 785: 121- 126.

Sengel E, İşçi B, Altındişli A (2012). Effects of different culture media on rooting in grafted grapevine. Ege Üniversitesi Ziraat Fakültesi Dergisi, 49 (2): 143-148.

Shawky I, Abou R, Zeinab Behairy, Salama M, Maryam Mostafa (1996). Growth and chemical composition regimes. 6th Conf. Agric. Dev. Res., Ain Shams Univ., Cairo, De. 17-19. Annals Agric. Sci., SP. Issue, 187-201.

Song YG, Lu WP, Wang J, Shen YJ, Wu ZS, Liu WD (2001). Study on promoting the rooting ability of hardwood cuttings of Amurien grape varieties. China Fruits 1: 4-7.

Southey JM, Jooste JH (1991). The Effect of Grapevine Rootstock on the Performance of Vitis vinifera L. (cv. Colombard) on a Relatively Saline Soil. S. Afr. J. Enol. Vitic. 12, 32-41.

Waite H, Whitelaw Weckert M, Torley P (2015). Grapevine propagation. Principles and methods for the production of high-quality grapevine planting material. New Zealand Journal of Crop and Horticultural Science 43(2): 144-161.

Weggler K, Carney C, Stone C (2008). Effect of fertilizer and water supply on the growth, nutrient status and photochemical efficiency of Eucalyptus pilularis seedlings in a phosphorus-deficient soil. Australian Forestry 71, 54-63.

Wilde AA, Corey RB, Lyer JG, Voigt GK (1985). Soil and plant analysis for tree culture. 3rd Edn. Oxford IBH Publishing Co. New Delhi, pp: 64-115.

Zhang X, Walker RR, Stevens RM, Prior LD (2002). Yield-salinity relationships of different grapevine (Vitis vinifera L.) scion-rootstock combinations. Aust. J. Grape Wine Res. 8, 150-156. 


\section{الملخص العربى}

\section{تأثير تركيزات أندول حمض البيوتريك وبيئات الزراعة المختلفة على نمو نوعى عقل عنب أصل الصولت كريك ( الرامسىى)}

عاطف مصطفى أبو عجيلة ، نيفين حسن فليفل ، أحمد عطية العايدى

$$
\text { قسم البساتين - كلية الزراعة - جامعة طنطا }
$$

- هدف الدراسة كان التركيز على تحسين نمو وإمتصاص العناصر الغذائية لعقل العنب أصل الصولت كريك ( الرامسى) والتى تواجه صعوبات فى عملية التجذير كاصل واعد فى إنتاج العنب تحت الظروف المناخية المعيقة للزراعة عموما. - لهذا الهحف تم تصميم تجربة كاملة العشوائية بثلاث مكررات لكل معاملة وكل مكررة تحتوى على عشرة عقل.

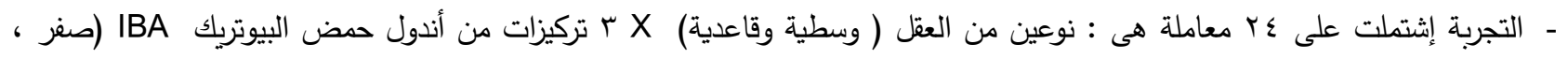

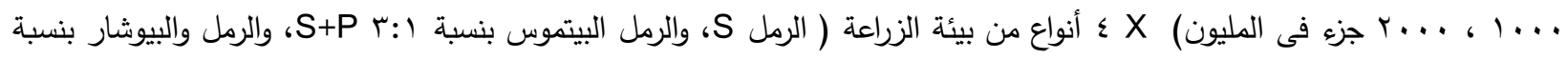

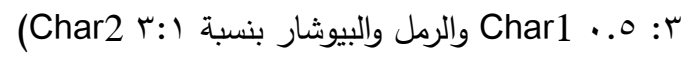
- سجلت العقل الوسطية أفضل النتائج فى كل القياسات تحت الدراسة كإستجابة لمعاملات أندول حمض البيوتريك وبيئات الزراعة المختبرة مقارنة بالعقل القاعدية.

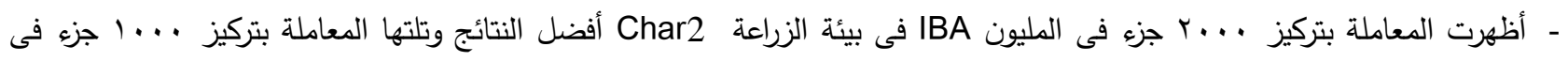
المليون فى نغس البيئة.

- تلى ذلك المعاملة ب IBA بترتيب تركيزه المذكور لنوعى العقل فى البيئة Char1 ثم كانت العقل المعاملة به فى بيئة S+P ـ

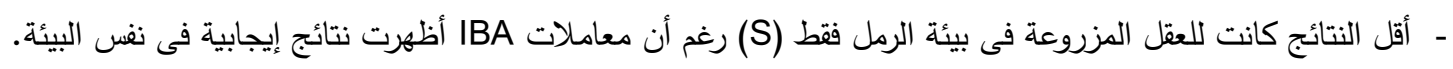
- وأخيرا توصى الراسة بالمعاملة بIBA فى بيئة الزراعة Char2 للتغلب على مشاكل إكثار عقل العنب أصل الصولت كريك ( الرامسى) ، كما توصى الدراسة بإستخدام العقل الوسطية لتقوقها على القاعدية فى هذا الصدد. 